PEDAGOGIA : Jurnal Ilmu Pendidikan

\title{
ANALISIS PENERAPAN KURIKULUM BERBASIS KKNI DI UNIVERSITAS NEGERI MEDAN
}

\author{
Beslina Afriani Siagian, Golda Novatrasio Sauduran Siregar \\ Universitas HKBP Nommensen Medan \\ beslinaafrianisiagian2014@gmail.com
}

\begin{abstract}
Abstrak
Tujuan penelitian ini adalah untuk mengadakan evaluasi pelaksanaan kurikulum berbasis KKNI pada Universitas Negeri Medan. Tujuan jangka pendek penelitian ini adalah untuk mengetahui keefektivan penerapan kurikulum KKNI dalam perguruan tinggi serta memperbaiki persepsi masyarakat, sedangkan jangka panjangnya adalah untuk menjadi bahan pertimbangan bagi pemerintah dalam menyetarakan kualifikasi lulusan dengan permintaan para penyedia lowongan pekerjaan (stakeholders), mempermudah sistem penyeleksian sertifikasi dosen (serdos) dan menyetarakan gaji dosen, serta menyetarakan gaji guru.Untuk memperoleh tujuan di atas, model evaluasi kurikulum yang digunakan adalah model CIPP (Context, Input, Process, Product). Berdasarkan penelitian yang telah dilakukan tampak bahwa penerapan kurikulum berbasis KKNI di Universitas Negeri Medan sudah dikatakan baik, meskipun masih perlu perbaikan pada beberapa aspek seperti kesiapan dosen, kelengkapan sarana dan prasarana, ketersediaan mitra magang, dan tentunya kesiapan mahasiswa. Universitas harus terus membenahi diri agar para lulusan mampu bersaing dengan lulusan lain, baik secara lokal, nasional, maupun internasional.
\end{abstract}

Kata Kunci: KKNI; Evalussi Kurikulum; CIPP

\begin{abstract}
The purpose of this study was to conduct an evaluation of the implementation of the SNPTbased curriculum at the State University of Medan. The short-term objective of this study is to determine the effectiveness of the application of IQF curriculum in universities and improve public perceptions, while the long term is to be taken into consideration for the government in equalizing graduate qualifications with the demand of job vacancy providers (stakeholders), facilitating the lecturer certification selection system and equalize lecturer salaries, and equalize teacher salaries. To obtain the above objectives, the curriculum evaluation model used is the CIPP model (Context, Input, Process, Product). Based on the research that has been done it appears that the implementation of the curriculum based on IQF at Medan State University has been said to be good, although it still needs improvement in several aspects such as lecturer readiness, completeness of facilities and infrastructure, availability of apprentice partners, and of course student readiness. Universities must continue to improve themselves so that graduates are able to compete with other graduates, both locally, nationally and internationally.
\end{abstract}

Keywords: KKNI; Curriculum Evaluation; CIPP 
PEDAGOGIA : Jurnal Ilmu Pendidikan

\section{A. PENDAHULUAN}

Derasnya arus globalisasi telah mengubah pola persaingan yang semakin ketat. Khusus negara peserta AFTA, persaingan tersebut tampak dalam beberapa aspek, di antaranya perkembangan Ipteks dan ketersediaan lapangan pekerjaan. Hal itu mengakibatkan terbentuknya kerangka kualifikasi nasional (selanjutnya disebut KKNI) sebagai upaya membendung persaingan tersebut. Abstrak Kerangka Kualifikasi Nasional Indonesia (KKNI) adalah salah satu rujukan nasional untuk meningkatkan mutu dan daya saing bangsa Indonesia di sektor sumberdaya manusia melalui pencapaian kualifikasi sumberdaya manusia Indonesia yang dihasilkan oleh sistem pendidikan dan sistem pelatihan kerja nasional, serta sistem penilaian kesetaraan capaian pembelajaran (Jono, 2016). Tujuan utamanya adalah untuk menyetarakan sumber daya manusia yang ada di Indonesia dengan yang ada di belahan dunia lain, dalam hal pendidikan dan pelatihan kerja di berbagai sektor. Itu sebabnya, penerapan KKNI (Peraturan Presiden No. 8 Tahun 2012 tentang KKNI) dalam kurikulum perlu merumuskan learning outcomes, yaitu menggambarkan secara jelas dan spesifik postur/sosok lulusan yang akan dihasilkan. (Nurdin, 2018).

Setakat itu, kompetensi masa depan yang diharapkan berupa: 1) kemampuan berkomunikasi, 2) berpikir jernih dan kritis, 3) mempertimbangkan segi moral suatu permasalahan, 4) menjadi warga negara yang bertanggung jawab, mencoba untuk mengerti dan toleran terhadap pandangan yang berbeda, 6) hidup dalam masyarakat yang mengglobal, 7) memiliki minat yang luas dalam kehidupan, 8) siap untuk bekerja, 9) memiliki kecerdasan sesuai bakat/minatnya, dan 10) memiliki rasa tanggung jawab terhadap lingkungan. Menurut Setiyawan (2017) lulusan harus memiliki standar kompetensi lulusan yang dapat dimanfaatkan dan relevan dengan lapangan kerja yang tersedia, yakni selain memiliki kompetensi utama, juga memiliki kompetensi pendukung dan pelengkap, sehingga lulusan tersebut memiliki daya saing tinggi dan luas dalam menghadapi dunia kerja baik secara nasional maupun internasional.

Namun, sejak KKNI digulirkan melalui Peraturan Presiden Republik Indonesia No.8 Tahun 2012 tentang Kerangka Kualifikasi Nasional Indonesia, ada beberapa masalah yang muncul, salah satunya mengenai adanya indikasi ketidaksesuaian kualifikasi dalam Standar Kompetensi Lulusan dengan fakta dan realita yang terjadi di lapangan (Casmini, 2014). Peraturan Presiden pada Pasal 8 menyatakan: Ayat (1) Pengakuan dan penyetaraan kualifikasi pada KKNI dengan kerangka kualifikasi negara lain atau sebaliknya, baik secara bilateral maupun multilateral dilakukan atas dasar perjanjian kerja sama saling pengakuan yang diatur sesuai dengan ketentuan 
PEDAGOGIA : Jurnal Ilmu Pendidikan

peraturan perundang-undangan, ayat (2) perjanjian kerja sama saling pengakuan sebagaimana dimaksud pada ayat (1) diatur oleh lembaga yang berwenang mengeluarkan notifikasi dan perjanjian kerja sama saling pengakuan.

Menyikapi Peraturan Presiden pada pasal 8 tersebut, muncul dua pertanyaan. Pertama, apakah dosen sudah memiliki kualifikasi yang sama dengan kualifikasi yang ditetapkan pemerintah? Kedua, apakah mahasiswa juga mampu mencapai kualifikasi yang telah dideskripsikan pada jenjang level 6? Selanjutnya, dari sudut pandang lain, ada kemungkinan kurikulum ini lebih menitikberatkan pada psikomotorik, bukan pada karakter.

\section{B. TINJAUAN PUSTAKA}

\section{Kerangka Kualifikasi Nasional Indonesia}

KKNI (Kerangka Kualifikasi Nasional Indonesia) merupakan acuan penjenjangan kualifikasi kompetensi untuk pengakuan kerja. KKNI telah dirumuskan oleh pemerintah melalui kementerian pendidikan pada tahun 2010 yang berfungsi sebagai acuan dalam pengembangan kurikulum. KKNI kemudian diundangkan melalui Peraturan Presiden Nomor 8 Tahun 2012 tentang Kerangka Kualifikasi Nasional Indonesia. Kehadiran KKNI merupakan acuan umum bagaimana kualifikasi seseorang mendapat pengakuan di dunia kerja (Solikhah, 2015).
Menurut (Mendikbud, 2010) dalam pengembangannya KKNI mengggunakan tiga strategi, yaitu: Pertama, KKNI menganut strategi kesetaraan kualifikasi seseorang yang diperoleh dari dunia pendidikan formal, nonformal, informal dan pengalaman bekerja. Kedua, KKNI mengakui kualifikasi pemegang ijazah yang akan bekerja maupun melanjutkan pendidikan di luar negeri, pertukaran pakar dan mahasiswa lintas negara atau pemegang ijazah dar luar negeri yang bekerja di Indonesia. Ketiga, KKNI mengakui kesetaraan kualifikasi capaian pembelajaran berbagai bidang keilmuan pada tingkat pendidikan tinggi, baik yang berada pada jalur pendidikan akademik, vokasi, profesi, serta melalui pengembangan karir yang terjadi di strata kerja, industri atau asosiasi profesi.

KKNI terdiri dari 9 jenjang kualifikasi. Deskripsi jenjang kualifikasi KKNI menurut Perpres No. 8 Tahun 2012 diuraikan sebagai berikut :

1) J e n jang 1 s a m pai 3 dikelompokkan dalam jabatan operator diduduki lulusan SD, SMP dan SMA.

2) J e n jang 4 s a m pai 6 dikelompokkan dalam jabatan teknisi atau analis, diduduki oleh lulusan D1, D2, D3, D4 dan Sarjana.

3) Jenjang 7 dikelompokkan dalam jabatan ahli, diduduki oleh lulusan pendidikan profesi.

4) Jenjang 8 dikelompokkan dalam 
PEDAGOGIA : Jurnal Ilmu Pendidikan

jabatan ahli diduduki oleh lulusan magister atau spesialis 1 .

5) Jenjang 9 dikelompokkan dalam jabatan ahli diduduki oleh lulusan doktor atau spesialis 2 .

\section{Model Evaluasi Kurikulum CIPP}

Model desain evaluasi kurikulum CIPP atau Context, Input, Proses, Product dikembangkan oleh Daniel Stufelbearn yang di dalamnya mengandung empat unsur cakupan (Sinambela, 2017) antara lain:

1) Context adalah penilaian yang berkaitan dengan usaha-usaha penemuan kebutuhan-kebutuhan peserta didik dengan berbagai masalah yang bersifat deskriptif dan komparatif. Kesimpulan dari penelitian dipergunakan untuk menentukan tujuan-tujuan sebagai titik pangkal bagi program pendidikan.

2) Input (masukan) yakni penilaian yang diharapkan dapat memberikan informasi mengenai bagaimana menggunakan sumber-sumber untuk mencapai tujuan. Penilaian ini berfungsi untuk mencari informasi yang dipergunakan menilai adanya beberapa alternatif strategi yang dapat dipilih sehingga mampu memberikan bantuan kepada pengambil keputusan untuk memilih dan merancang prosedur yang kiranya sesuai dengan mencapai tujuan program
3) Proses yaitu penilaian yang dilakukan pada saat program berlangsung, sehingga mampu menggambarkan kejadian-kejadian dan kegiatankegiatan prosedur untuk mengetahui kekurangankekurangan dalam desain pembelajaran. Penilaian ini berfungsi untuk membantu dalam pengambilan keputusan dalam berbagai kesulitan-kesulitan

4) Product yakni penilaian yang berupaya untuk mengukur dan menafsirkan pencapaian suatu program. Hasilnya dipergunakan sebagai bahan perbandingan antara harapan dan hasil aktual.

\section{METODE PENELITIAN}

Penelitian ini menggunakan pendekatan deskriptif. Data diperoleh dengan menggunakan teknik wawancara, observasi, dan dokumentasi. Model evaluasi yang digunakan adalah model yang mengkaji empat komponen sekaligus, yakni context, input, process, dan product. Hal itu dilakukan dengan: a) analisis konteks: harapan pemerintah melalui KKNI, dukungan masyarakat terhadap KKNI, dan kebijakan pemerintah dalam menerapkan KKNI, b) analisis input: visi, misi, tujuan, dan sasaran universitas, buku pegangan dosen, buku mahasiswa, pelatihan KKNI, manajamen pembelajaran, dan layanan kemahasiswaan, c) analisis proses: proses 
pembelajaran, proses pemberian tugas, proses pengadaan ujian dan proses penilaian, dan d) analisis produk: nilai akhir semester.

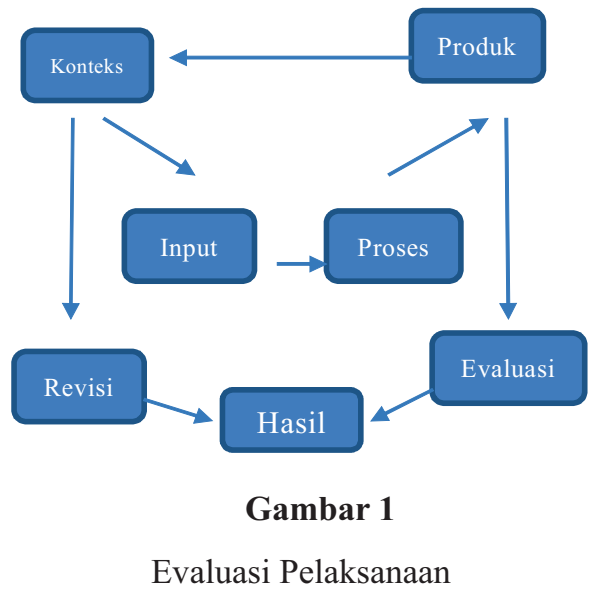

\section{HASIL DAN PEMBAHASAN}

\section{Deskripsi Kualifikasi}

Deskripsi kualifikasi ini merupakan tingkat capaian pembelajaran yang disepakati secara nasional, disusun berdasarkan hasil pendidikan atau pelatihan yang diperoleh melalui pendidikan formal, nonformal, informal, atau pengalaman kerja (Kemendiknas, 2012).

\section{Efektivitas KKNI dengan Model Evaluasi Kurikulum CIPP}

Untuk memperoleh hasil yang maksimal, penelitian ini menggunakan model evaluasi kurikulum CIPP (context, input, process, dan product). Aspek tersebut dijelaskan satu persatu dalam pemaparan di bawah ini.

\section{A. Analisis Konteks}

Evaluasi context menentukan kebutuhan, masalah-masalah, asset, dan kesempatan untuk membantu pengambil keputusan menetapkan tujuan dan prioritas serta membantu kelompok lebih luas dalam pengambilan tujuan, prioritas, dan hasil. Dalam hal ini, harapan pemerintah melalui KKNI, dukungan (persepsi) masyakat terhadap KKNI, dan kebijakan pemerintahan dalam menerapkan KKNI pada pendidikan tinggi, merupakan beberapa poin yang terdapat dalam aspek konteks.

P e r t a ma, pe m e r in t a h mengharapkan, "KKNI harus mampu menjadi rujukan penataan tenaga kerja Indonesia di bidang multimedia dengan menetapkan jenjang kualifikasi yang jelas serta kesetaraannya dengan negara-negara lain di dunia. Dengan menerapkan Kerangka Kualifikasi Nasional Indonesia (KKNI) maka dampak yang kita peroleh antara lain adalah meningkatnya kuantitas sumberdaya manusia Indonesia yang bermutu dan berdaya saing internasional" (Kepala Badan Penelitian dan Pengembangan Sumberdaya Manusia Kementerian Komunikasi dan Informatika Basuki Yusuf Iskandar, Kominfo).

Selanjutnya, KKNI merujuk sistem kualifikasi negara lain, seperti Scotlandia, Eropa, Amerika, dan kelompok negara ASEAN. European Qualification Framework (EQF) terbagi atas delapan tingkat penjenjangan kualifikasi. Dimulai dari kemampuan pengetahuan dasar sampai pada kemampuan tertinggi seperti lulusan doktor. EQF menganut konsep 
PEDAGOGIA : Jurnal Ilmu Pendidikan

pembelajaran sepanjang hayat. Berbeda dengan itu, Australian Qualification Framework (AQF) merujuk pada sistem kualifikasi yang memilah sector pendidikan dan pelatihan dalam tiga bagian, yakni sekolah menengah, pelatihan dan pendidikan vokasi, dan pendidikan tinggi. Namun, perlu dipahami sistem kualifikasi AQF dianggap terlalu rinci sehingga belum tepat digunakan di Indonesia. Itu sebabnya, EQF yang dianggao yang paling tepat, maka tidak heran EQF memberikan pengaruh yang kuat dalam pengembangan dan penyusunan KKNI. Adapun penggunaan sistem kualifikasi oleh pemerintah agar produk lulusan KKNI dapat diterima oleh negara lain sehingga tenaga kerja Indonesia terserap dengan cepat.

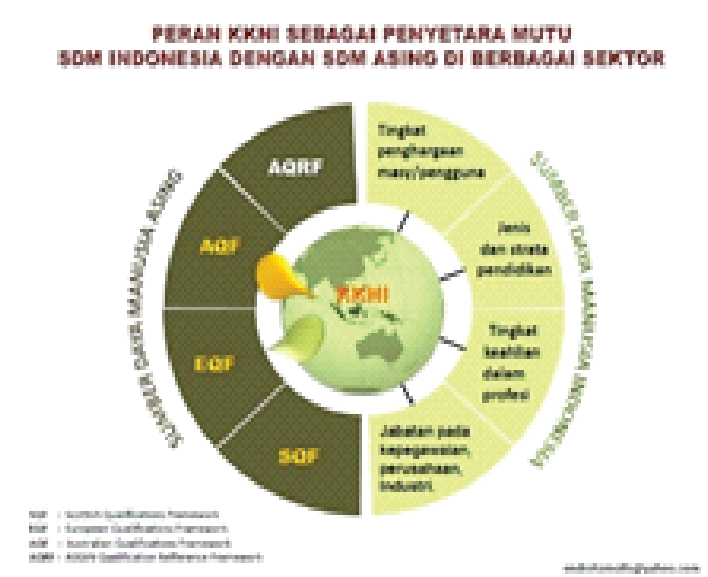

Gambar 2

Peran KKNI

Kedua, dukungan masyarakat terhadap KKNI terlihat cukup positif. Meskipun tidak berhasil mewawancarai para mitra (stakeholder), namun tanggapan mahasiswa sebagai pelaku
KKNI ini cukup positif. Mereka menjadi kreatif dan kapabel mengerjakan riset. Selain itu, dosen juga berhasil diwawancarai mengenai persepsi mereka. Berikut persepsi yang berhasil didata:

1) KKNI adalah kurikulum yang menitikberatkan kompetensi atau learning outcomes sehingga kompetensi yang diharapkan dari lulusan-lulusan ditanamkan melalui materi mata kuliah.

2) KKNI mengacu pada kebutuhan stakeholder.

3) Perlu diingat tiga kata kunci dalam KKNI yakni melaraskan, m e n y a $n d i n g k$ a,$\quad d$ a $n$ mengintegrasikan.

4) KKNI merupakan kualifikasi yang menjawab tantangan berbasis produk.

5) KKNI mengintegrasikan atau m e n y a n ing k a n a n t a ra keterampilan, pengetahuan, dan pasar kerja. Perbedaan dengan kurikulum sebelumnya adalah tidak menyandingkan atau tidak terikat antara keterampilan atau pengetahuan dengan pasar kerja.

Berdasarkan konsep-konsep di atas, dosen memiliki persepsi yang hampir sama mengenai kurikulum berbasis KKNI. Hal ini didukung oleh hasil wawancara yang menyatakan bahwa setiap dosen sudah pernah mengikuti pelatihan (sosialisasi) kurikulum tersebut yang diadakan oleh pihak universitas. 
PEDAGOGIA : Jurnal Ilmu Pendidikan

Artinya, dosen sudah memiliki persepsi yang sesuai dengan konteks yang diharapkan oleh pemerintah sehingga pelaksanaannya di kelas terealisasi dengan baik.

Ketiga, dalam upaya melakukan kualifikasi terhadap lulusan perguruan tinggi di Indonesia, pemerintah telah menerbitkan Perpres No.08 Tahun 2012 tentang Kerangka Kualifikasi Nasional Indonesia (KKNI) dan lampirannya_ yang menjadi acuan dalam penyusunan capaian pembelajaran lulusan dari setiap jenjang pendidikan secara nasional, yakni juknis Perpres ini Permendikbud no. 73 Tahun 2013. Terbitnya Perpres No. 08 Tahun 2012 dan UU PT No. 12 Tahun 2012 Pasal 29 ayat (1), (2), dan (3) telah berdampak pada kurikulum dan pengelolaannya di setiap program. Kurikulum yang pada awalnya mengacu pada pencapaian kompetensi menjadi mengacu pada capaian pembelajaran (learning outcomes).

Berdasarkan ketiga aspek di atas, dapat disimpulkan bahwa analisis konteks kurikulum berbasis KKNI cenderung baik. KKNI ini diharapkan akan mengubah cara melihat kompetensi seseorang, tidak lagi semata Ijazah tapi dengan melihat kepada kerangka kualifikasi yang disepakati secara nasional

\section{B. Analisis Input}

Input dianalisis berdasarkan visi, misi, tujuan, dan sasaran Universitas
Negeri Medan. Berikut pemaparan keempat item tersebut.

1. Visi : Menjadi universitas yang unggul di bidang pendidikan, rekayasa industri dan budaya

\section{Misi :}

a) Menyelenggarakan pendidikan, penelitian, dan pengabdian kepada masyarakat serta kerjasama dengan berbagai instansi dalam dan luar negeri.

b) Mengembangkan Unimed menjadi teaching and research institution yang unggul.

c) Mengembangkan rekayasa industri dan teknologi yang kreatif.

d) Mengembangkan budaya ilmiah dan budaya etnik, kewirausahaan.

e) Membina iklim organisasi dan suasana akademik yang sehat

\section{Tujuan Strategis:}

a) Menghasilkan lulusan yang unggul, professional, berkarakter, memiliki kecerdasan intelektual, keterampilan kewirausahaan dan berwawasan kebangsaan.

b) Menghasilkan, mengembangkan, dan menyebarluaskan ilmu pengetahuan, teknologi, dan/ atau seni untuk mewujudkan tridharma perguruan tinggi.

c) Menghasilkan berbagai kesepakatan dan kegiatan kerjasama tingkat lokal, nasional, regional dan internasional untuk mendukung percepatan pembangunan daerah dan nasional. 
PEDAGOGIA : Jurnal Ilmu Pendidikan

d) Menghasilkan karya ilmiah untuk mengembangkan Unimed sebagai pusat inovasi pembelajaran dan penelitian.

e) Menghasilkan karya produk inovatif dan kreatif yang mampu memberikan nilai tambah pada dunia usaha dan dunia industri (DUDI).

f) Menghasilkan lulusan yang berbudaya ilmiah berbasis budaya etnik dan memiliki budaya etnik dan memiliki budaya kewirausahaan serta mengembangkan organisasi yang berbudaya ilmiah.

g) Mengembangkan Unimed sebagai organisasi yang sehat dan suasana akademik yang kondusif.

Visi, misi, dan tujuan strategis di atas sejalan dengan konsep kurikulum berbasis KKNI. KKNI yang menitikberatkan kompetensi atau learning outcomes dapat menghasilkan lulusan yang unggul, profesional, berkarakter, memiliki kecerdasan intelektual, keterampilan kewirausahaan dan berwawasan kebangsaan (seperti dalam tujuan strategis yang pertama). Selain itu, KKNI yang mengintegrasikan atau menyandingkan antara keterampilan, pengetahuan, dan pasar kerja juga dapat menghasilkan karya produk inovatif dan kreatif yang mampu memberikan nilai tambah pada dunia usaha dan dunia industri (DUDI) (seperti dalam tujuan strategis yang kelima). Artinya, KKNI dapat digunakan untuk mencapai visi, misi, dan tujuan strategis tersebut.
Selanjutnya, poin lain yang termasuk dalam input adalah buku pegangan dosen, buku mahasiswa, pelatihan (sosialisasi), manajemen pembelajaran, dan layanan kemahasiswaan. Berikut penjelasannya.

\section{1) Buku Pegangan Dosen}

Buku tidak selalu menjadi bahan ajar satu-satunya dalam pembelajaran. Pada era digitalisasi ini, jurnal dapat diunduh secara online dari system portal e-learnig dapat digunakan sebagai referensi. Meskipun demikian, menurut pengakuan salah satu dosen Universitas Negeri Medan, pada tahun 2018 telah diterbitkan bahan ajar berbasis KKNI untuk mata kuliah umum, seperti Bahasa Indonesia, Agama, dan PKN untuk menunjang pembelajaran. Sesuai dengan hasil wawancara dan observasi di lapangan, buku pegangan dosen yang digunakan sebagai rujukan utama dalam kurikulum berbasis KKNI ini sudah sesuai. Artinya, telah memenuhi kriteria: kesesuaian isi, kebenaran, kelengkapan, dan keterbacaan. Namun demikian, dosen cenderung mengarahkan mahasiswa untuk mencari buku pembanding sekitar 2-3 buku lagi. Meski pada akhirnya, kebanyakan mahasiswa tetap menjadi buku dari perpustakaan sebagai pembanding buku utama. Tetapi perlu diketahui, satu catatan dalam poin ini, masih ada beberapa dosen yang masih tetap menggunakan buku diktat (yang belum memiliki ISBN) sebagai rujukan utama dalam 
PEDAGOGIA : Jurnal Ilmu Pendidikan

pembelajaran. Hal ini sangat disayangkan mengingat pentingnya keabsahan buku.

\section{2) Buku Mahasiswa}

Buku pegangan yang digunakan mahasiswa adalah buku yang sama dengan buku pegangan dosen. Artinya, buku tersebut juga memenuhi kriteria: kesesuaian isi, kebenaran, kelengkapan, dan keterbacaan. Hanya saja, mahasiswa cenderung diarahkan untuk mencari buku pembanding sebagai referensi tambahan. Dalam hal ini, menurut hasil wawancara dengan mahasiswa, buku pembanding tersebut tidak menjadi kewajiban. Itu sebabnya, mahasiswa hanya meminjam buku perpustakaan sebagai buku pembanding.

\section{3) Pelatihan (Sosialisasi)}

Pelatihan mengenai kurikulum berbasis KKNI dilakukan hampir tiap semester, baik terhadap dosen maupun terhadap mahasiswa. Untuk dosen, pelatihan diadakan pelatihan mengenai proses dan produk pembelajaran KKNI. Di antara mereka bahkan menjadi pembicara dalam tajuk pelatihan yang sama. Sedangkan untuk mahasiswa, pelatihan diadakan untuk mengadakan sosialisai mengenai pemberian tugas dan proses penilaian. Sesuai dengan hasil wawancara, pelatihan (sosialisasi) memenuhi kriteria: kesesuaian materi, kesesuaian kompetensi, dan kesesuaian alokasi waktu. Mahasiswa yang memperoleh pelatihan hanya stambuk
2017. Adapun stambuk 2015 dan 2016 tidak memperoleh pelatihan, tetapi diwajibkan mengerjakan tugas serupa dengan konsep KKNI.

\section{4) Manajemen Pembelajaran}

Da $1 \mathrm{am} \mathrm{hal} \mathrm{manaje} \mathrm{men}$ pembelajaran, ada lima aspek yang perlu diperhatikan. Pertama, kesesuaian pengelompokan mata kuliah dnegan profil lulusan. Dalam hal ini, Universitas Negeri Medan telah menyesuaikan bobot kelompok mata kuliah dengan profil lulusan yang ditargetkan. Meski profil lulusan utama tentu menjadi guru, namun disediakan mata kuliah tertentu untuk mendukung profil lulusan selain guru. Kedua, penyusunan RPS. Semua dosen yang berhasil diwawancara mengaku bahwa silabus, kontrak kuliah, dan RPS selalu disusun dan diserahkan kepada Ketua Program Studi sebelum pembelajaran semester baru dimulai. Pada kesempatan berbeda, mahasiswa mengaku hal serupa. Bahkan tugas untuk satu semester sudah dijadwalkan dalam kontrak kuliah tersebut. Hal ini tentu merupakan manajemen yang baik. Pembelajaran yang baik dipengaruhi persiapan perangkat pembelajaran yang baik. Ketiga, pemberian tugas. Dalam hal ini, ada beberapa dosen secara rutin memberikan tugas tiap pertemuan sehingga mahasiswa kesulitan menyelesaikan tugas-tugas tersebut, namun ada juga yang tidak secara rutin memberikan tugas. Namun yang perlu 
diperhatikan, pengumpulan tugas rutin tidak konsisten sehingga mahasiswa sering sekali tergesa-gesa mengerjakan tugas-tugas tersebut. Selain itu, tidak semua dosen memberikan enam tugas itu kepada mahasiswa. Memasuki semester dua, dosen memberikan toleransi dalam pengerjaan tugas. Keempat, linearitas bidang ilmu dosen dengan mata kuliah yang diampu. Dalam hal ini, sesuai dengan hasil wawancara, masih ada beberapa dosen yang mengajar mata kuliah yang tidak sesuai dengan bidang ilmunya. Hal ini membuat mahasiswa kesulitan mengikuti pembelajaran. Yang terakhir, kesesuaian visi misi universitas dengan deskripsi mata kuliah. Hal ini juga sudah tepat sesuai dengan penjelasan sebelumnya.

\section{5) Layanan Kemahasiswaan}

Terkait dengan layanan kemahasiswaan, program studi pada Universitas Negeri Medan melalui dosen yang diwawancarai mengaku bahwa program studi memfasilitasi mahasiswa untuk dibimbing di kantor. Selain itu, dosen PA (Pembimbing Akademik) juga difungsikan untuk membantu mahasiswa yang kesulitan dalam menghadapi masalah akademik. Namun perlu juga diketahui, mahasiswa mengaku, pertemuan dengan dosen PA diadakan hanya ketika meminta tanda tangan KRS saja. Tidak ada waktu khusus bagi mahasiswa dibimbing secara akademis oleh dosen PA.

\section{C.Analisis Proses \\ 1) Proses Pembelajaran}

Pola dan strategi pembelajaran yang terpusat pada dosen seperti yang dipraktikkan pada saat ini sudah tidak memadai untuk mencapai tujuan pendidikan khususnya yang berbasis kompetensi karena strategi mengajar bagi seorang dosen merupakan bagian yang sangat penting dalam proses pembelajaran. (S. Nasution dalam Suteja, 2017,hlm 93). Berkaitan dengan itu, proses pembelajaran dalam kurikulum berbasis KKNI harus berubah dari teacher centered learning menjadi student centered learning. Berikut peralihan kedua konsep tersebut.

Tabel 1

Perbedaan TCL dengan SCL

\begin{tabular}{|c|c|}
\hline $\begin{array}{l}\text { Pengetahuan ditransfer } \\
\text { dari dosen ke } \\
\text { mahasiswa }\end{array}$ & 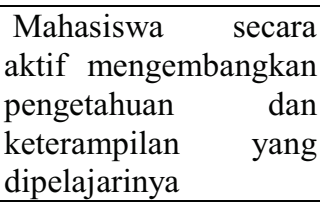 \\
\hline $\begin{array}{lr}\text { Mahasiswa } & \text { menerima } \\
\text { pengetahuan } & \text { secara } \\
\text { pasif } & \end{array}$ & $\begin{array}{l}\text { Mahasiswa secara aktif } \\
\text { terlibat dalam } \\
\text { mengelola } \\
\text { pengetahuan }\end{array}$ \\
\hline $\begin{array}{lr}\text { Lebih } & \text { menekankan } \\
\text { pada } & \text { penguasaan } \\
\text { materi } & \end{array}$ & $\begin{array}{l}\text { Tidak hanya } \\
\text { menekankan pada } \\
\text { penguasaan materi } \\
\text { tetapi juga } \\
\text { mengembangkan } \\
\text { karakter mahasiswa } \\
\text { (long life character) }\end{array}$ \\
\hline $\begin{array}{lr}\text { Fungsi } & \text { dosen } \\
\text { pengajar } & \text { atau } \\
\text { pemberi } & \text { informasai } \\
\text { utama atau evaluator }\end{array}$ & $\begin{array}{l}\text { Fungsi dosen sebagai } \\
\text { fasilitator dan evaluasi } \\
\text { dikerjakan bersama } \\
\text { dengan mahasiswa }\end{array}$ \\
\hline $\begin{array}{lr}\text { Proses } & \text { pembelajaran } \\
\text { dan } & \text { penilaian } \\
\text { dilakukan } & \text { secara } \\
\text { terpisah } & \end{array}$ & $\begin{array}{lr}\text { Proses } & \text { pembelajaran } \\
\text { dan } & \text { penilaian } \\
\text { dilakukan } & \text { dengan } \\
\text { saling } & \\
\text { berkesinambungan an } \\
\text { terintegrasi }\end{array}$ \\
\hline
\end{tabular}


PEDAGOGIA : Jurnal Ilmu Pendidikan

\begin{tabular}{|c|c|}
\hline $\begin{array}{ll}\text { Menekankan } & \text { pada } \\
\text { jawaban yang } & \text { benar } \\
\text { saja } & \end{array}$ & $\begin{array}{l}\text { Kesalahan dinilai dapat } \\
\text { menjadi salah satu } \\
\text { sumber belajar }\end{array}$ \\
\hline $\begin{array}{l}\text { Sesuai untuk } \\
\text { mengembangkan ilmu } \\
\text { dalam satu disiplin saja }\end{array}$ & $\begin{array}{lr}\text { Sesuai } & \text { untuk } \\
\text { pengembangan } & \text { ilmu } \\
\text { dengan } & \text { cara } \\
\text { pendekatan } & \\
\text { interdisipliner } & \\
\end{array}$ \\
\hline $\begin{array}{l}\text { Iklim belajar lebih } \\
\text { individualis } \\
\text { kompetitif }\end{array}$ & $\begin{array}{lr}\text { Iklim } & \text { yang } \\
\text { dikembangkan } & \text { lebih } \\
\text { kolaboratif, suportif, } & \\
\text { dan kooperatif } & \end{array}$ \\
\hline $\begin{array}{lr}\text { Hanya } & \text { mahasiswa } \\
\text { yang } & \text { dianggap } \\
\text { melakukan } & \text { proses } \\
\text { pembelajaran } & \end{array}$ & $\begin{array}{l}\text { Mahasiswa dan dosen } \\
\text { belajar bersama di } \\
\text { dalam } \\
\text { mengembangkan } \\
\text { pengetahuan, konsep, } \\
\text { dan keterampilan }\end{array}$ \\
\hline $\begin{array}{ll}\text { Perkuliahan } & \\
\text { merupakan bagian } \\
\text { terbesar dalam proses } \\
\text { pembelajaran }\end{array}$ & $\begin{array}{l}\text { Mahasiswa dapat } \\
\text { belajar tidak hanya dari } \\
\text { perkuliahan saja, tetapi } \\
\text { dapat menggunakan } \\
\text { berbagai cara dan } \\
\text { kegiatan }\end{array}$ \\
\hline $\begin{array}{l}\text { Penekanan } \\
\text { tuntasnya } \\
\text { pembelajaran }\end{array}$ & $\begin{array}{l}\text { Penekanan pada } \\
\text { pencapaian kompetensi } \\
\text { peserta didik dan } \\
\text { bukan tuntasnya materi }\end{array}$ \\
\hline $\begin{array}{l}\text { Penekanan pada } \\
\text { bagaimana cara dosen } \\
\text { melakukan } \\
\text { pembelajaran }\end{array}$ & $\begin{array}{lr}\text { Penekanan } & \text { pada } \\
\text { bagaimana } & \text { cara } \\
\text { mahasiswa } & \text { dapat } \\
\text { belajar } & \text { dengan } \\
\text { menggunakan berbagai } \\
\text { bahan pelajaran, } \\
\text { metode interdisipliner, } \\
\text { penekanan } \\
\text { Problem pada } \\
\begin{array}{l}\text { Learning dan } \\
\text { Competency }\end{array} \\
\end{array}$ \\
\hline $\begin{array}{l}\text { Sesuai untuk } \\
\text { mengembangkan ilmu } \\
\text { dalam satu disiplin saja }\end{array}$ & $\begin{array}{lr}\text { Sesuai } & \text { untuk } \\
\text { pengembangan } & \text { ilmu } \\
\text { dengan } & \text { cara } \\
\text { pendekatan } & \\
\text { interdisipliner } & \end{array}$ \\
\hline
\end{tabular}

Berdasarkan perbedaan dua konsep di atas, KKNI tentu lebih menekankan pada student centered learning yang menjadikan mahasiswa lebih kreatif dan menuntut dosen untuk mempersiapkan pembelajaran dengan baik agar tercipta iklim yang kolaboratif, suportif, dan kooperatif. Setakat itu, berdasarkan hasil wawancara dengan dosen Universitas
Negeri Medan, berikut metode yang digunakan dalam pembelajaran berbasis KKNI.

a) Metode blended learning, yakni gabungan dari beberapa metode, disesuaikan dengan kompetensi dari jurusan masing-masing.

b) Metode diskusi di dalam kelas, kemudian memberikan tugas proyek ke lapangan. Perkuliahan tidak selalu di dalam kelas, bisa saja di perpustakaan, museum, ataupun di sekolah. Hal ini sangat sesuai dengan konsep SCL di atas.

c) Metode learning eksperiments yang membuat mahasiswa mempunyai pengalaman mahasiswa, membuat soal-soal dan dijawab sesuai pertanyaan yang dikerjakan, mempresentasikan jawaban tersebut di depan ruangan.

d) Metode student center learning; persis sama dengan penjelasan di atas

e) Metode yang digunakan adalah metode pembelajaran orang dewasa dengan anggapan lebih fokus kepada bagaimana mereka supaya kemandiriannya tumbuh.

Selain itu, ada beberapa catatan mengenai masalah proses pembelajaran yang berhasil dihimpun dari wawancara dengan mahasiswa:

a) Dosen cenderung tidak mengajarkan perekayasaan ide kepada mahasiswa. Mahasiswa cenderung menemukan sendiri, padahal di antara enam tugas wajib, perekayasaan ide merupakan 
PEDAGOGIA : Jurnal Ilmu Pendidikan

yang paling sulit.

b) Dosen cenderung kurang kreatif dalam proses pembelajaran, padahal dikenal memiliki kemampuan kognisi yang baik.

c) Ada beberapa dosen yang lebih sering memberikan tugas dari media sosial seperti mengirim lewat e-mail sehingga mahasiswa kesulitan mengerjakan tugas yang diberikan oleh dosen.

d) Ada beberapa dosen yang sering tidak hadir dan hanya memberikan format laporan yang harus dikerjakan sehingga laporan tersebut dikerjakan begitu saja, bahkan tanpa feed back dari dosen.

\section{2) Proses Penilaian}

Sesuai dengan konsep Standar Nasional Dikti tahun 2015, capaian pembelajaran KKNI didasarkan pada empat hal, yakni sikap dan tata nilai penguasaan pengetahuan, kemampuan kerja, serta wewenang dan tanggung jawab. Keempat hal ini tampak pada pemberian enam tugas, yakni tugas rutin, critical book report, critical journal report, rekayasa ide, mini research, dan project sehingga proses penilaian didasarkan pada hasil keenam tugas tersebut.

Penilaian proses dan hasil belajar mahasiswa dalam konsep kurikulum berbasis KKNI (Permenristekdikti, No. 44 Tahun 2015) mencakup:

a) prinsip penilaian b) teknik dan instrumen penilaian

c) mekanisme dan prosedur penilaian

d) pelaksanaan penilaian

e) pelaporan penilaian, dan

f) kelulusan mahasiswa

Tabel 2

Prinsip Penilaian

\begin{tabular}{ll}
\hline Otentik & Berorientasi pada proses belajar \\
& yang berkesinambungan dan \\
& hasil belajar yang mencerminkan \\
& kemampuan mahasiswa pada saat \\
& proses pembelajaran berlangsung \\
\hline Obyektif & $\begin{array}{l}\text { Didasarkan pada standar yang } \\
\text { disepakati antara dosen dan }\end{array}$ \\
& mahasiswa serta bebas dari \\
& pengaruh subjektivitas penilai \\
& dan yang dinilai \\
\hline Akuntabel & Sesuai dengan prosedur dan \\
& kriteria yang jelas, disepakati \\
& pada awal kuliah, dan dipahami \\
& oleh mahasiswa. \\
\hline Transparan & Dapat diakses oleh semua \\
& pemangku kepentingan \\
\hline
\end{tabular}

Teknik penilaian tersebut terdiri atas observasi, partisipasi,unjuk kerja, tes tertulis, tes lisan, dan angket. Selanjutnya, berikut disajikan kualifikasi dan kisaran penilaian (Sugeng \& Raihan, 2016).

Tabel 3

Kisaran Nilai KKNI

\begin{tabular}{ccc}
\hline Nilai Angka & Huruf & Bobot \\
\hline $80,00-100$ & $\mathrm{~A}$ & 4 \\
\hline $75,00-79,99$ & $\mathrm{~A}^{-}$ & 3,7 \\
\hline $72,00-74,99$ & $\mathrm{~B}^{+}$ & 3,3 \\
\hline $68,00-71,99$ & $\mathrm{~B}$ & 3 \\
\hline $65,00-67,99$ & $\mathrm{~B}^{-}$ & 2,7 \\
\hline $62,00-64,99$ & $\mathrm{C}^{+}$ & 2,3 \\
\hline $55,00-61,99$ & $\mathrm{C}$ & 2 \\
\hline $41,00-54,99$ & $\mathrm{D}$ & 1 \\
\hline $0-40,99$ & $\mathrm{E}$ & 0 \\
\hline
\end{tabular}

Penjelasan di atas merupakan proses serta hal-hal yang berkaitan dengan penilaian dalam kurikulum berbasis KKNI. Berikut hasil wawancara dari 
beberapa dosen yang berhasil didata:

a) Penilaian dilakukan dengan menggabungkan PAP (Penilaian Acuan Patokan) dan PAN (Penilaian Acuan Norma). Mengapa? Karena kalau dibuat hanya PAP, terkadang mahasiswa tidak lulus, sehingga harus dibuatPAN.

b) Prinsip penilaian dilakukan secara transparan dan produk-produk mahasiswa dipajang.

c) Penilaian dilakukan dengan authentic assessment, menilai apa yang sebenarnya dinilai, yakni: kemampuan yang holistic, keterampilan, pengetahuan, dan sikap.

d) Penilaian dengan sistem PAP, tapi tidak mengenal nilai $\mathrm{D}$.

e) Melakukan observasi produk, yakni melakukan penilaian F1, F2, F3 kemudian tugas rutin

f) Persentase penilaian antara sikap, pengetahuan, dan keterampilan disesuaikan dengan kondisi tertentu

Jika target penilaian tidak dapat dicapai oleh mahasiswa, maka akan diadakan remedial berupa tugas tambahan. Selain itu, diadakan layanan bimbingan kepada mahasiswa secara kognitif di kantor program studi. Selanjutnya, dosen juga memberikan kesempatan bagi mahasiswa untuk memperbaiki tugas-tugasnya manakala tidak memenuhi kriteria.

Namun yang menjadi catatan dalam poin ini, mahasiswa kurang puas dengan nilai yang diperoleh karena penilaian cenderung menitikberatkan nilai ujian, padahal ada banyak tugas yang seharusnya dapat menjadi pertimbangan. Dosen tidak terbuka dalam melakukan penilaian sehingga mahasiswa bingung dengan perolehan nilai yang tidak sesuai dengan harapan.

\section{D.Analisis Produk}

Pada dasarnya, produk kurikulum berbasis KKNI ini adalah lulusan yang siap menjadi tenaga kerja dan bersaing dengan sumber daya manusia asing, namun hal itu tidak dapat diperoleh karena belum ada lulusan Universitas Negeri Medan yang mendapat kualifikasi ini mengingat pengadaannya baru dimulai pada tahun 2017. Itu sebabnya, analisis hanya dilakukan pada hasil belajar mahasiswa. Sesuai dengan penjelasan pada peniaian, mahasiswa mengaku kurang puas sebab dosen kurang transparan dalam menunjukkan hasil penilaian.

Berdasarkan semua penjelasan di atas, diperoleh data kuantitatif semua aspek dalam penelitian ini yang diperoleh dari sembilan aspek pada 18 orang sampel di atas adalah sebagai berikut: Pertama, aspek masyarakat (konteks) memperoleh nilai 4. Kedua, aspek buku pegangan dosen pada kriteria kesesuaian isi $(3,8)$, kebenaran $(3,8)$, kelengkapan $(3,8)$, dan keterbacaan buku $(3,8)$. Selanjutnya, aspek buku mahasiswa pada kriteria kelengkapan $(3,8)$, keterbacaan $(3,7)$, kegrafikan $(3,6)$, dan kualitas cetakan 
PEDAGOGIA : Jurnal Ilmu Pendidikan

buku $(3,4)$. Kemudian, aspek pelatihan KKNI pada kriteria kesesuaian materi $(3,9)$, kesesuaian kompetensi $(3,9)$, dan kesesuaian alokasi waktu $(3,6)$. Lalu, aspek manajemen pembelajaran pada kriteria kesesuaian pengelompokan mata kuliah dengan profil lulusan $(3,8)$, penyusunan RPS $(3,8)$, Pemberian tugas $(3,1)$, linearitas bidang ilmu dosen dengan mata kuliah yang diampu $(3,1)$, keseuaian visi misi universitas dengan deskripsi mata kuliah $(3,8)$. Selanjutnya, aspek layanan kemahasiswaan pada kriteria keterlaksanaan bantuan kesulitan belajar dengan pengayaan $(3,7)$, keterlaksanaan konsultasi $(3,5)$, keterlaksanaan administrasi kemahasiswaan $(3,5)$, dan pengadaan sosialisasi KKNI $(3,5)$. Kemudian, aspek proses pembelajaran pada kriteria dosen memiliki silabus dan RPS berbasis KKNI $(3,8)$, pembelajaran sesuai KKNI $(3,5)$, dosen mengajarkan perekayasaan ide $(2,1)$, kemampuan dosen mengajarkan keterampilan kepada mahasiswa $(3,4)$, dan dosen secara konsisten memberikan tugas rutin pada setiap pertemuan $(3,3)$. Selanjutnya, aspek proses penilaian pada kriteria penilaian untuk tugas rutin $(3,3)$, critical book report (3,3), critical journal report $(3,2)$, rekayasa ide $(2,7)$, mini research $(3,3)$, dan project $(3,2)$. Yang terakhir, aspek hasil belajar memperoleh nilai 3,5.

\section{Kendala Pelaksanaan Kurikulum Berbasis KKNI}

Pertama, dosen belum sepenuhnya siap menerapkan KKNI dalam pembelajaran. Seperti penjelasan sebelumnya mengenai Student Centered Learning, mahasiswa dan dosen belajar bersama di dalam mengembangkan pengetahuan, konsep, dan keterampilan. Sementara kenyataannya, dosen cenderung menuntut mahasiswa aktif mengerjakan tugas-tugas, tetapi tidak memfasilitasi dan membantu mahasiswa menyelesaikan masalah dalam mengerjakan tugas tersebut.

Kedua, sarana dan prasarana juga tidak memadai dalam mengembangkan pembelajaran dengan konsep KKNI. Dibutuhkan sistem teknologi informasi yang kapabel untuk membantu mahasiswa belajar secara digital. Selain itu, laboratorium atau sejenisnya juga sangat dibutuhkan untuk mengembangkan kreativitas belajar. Selanjutnya, dibutuhkan ruangan belajar selain ruangan kelas formal yang menjadi wadah bagi mahasiswa untuk belajar dan diskusi bersama sesame mahasiswa. Dan ada banyak lagi fasilitas yang dibutuhkan untuk mengembangkan kreativitas belajar. Ketiga, sulitnya pihak kampus, khususnya program studi dalam menemukan mitra magang. Penerapan KKNI pada universitas berbasis pendidikan seperti Universitas Negeri Medan, PPL (Program Pengalaman Lapangan) telah diubah menjadi magang. Pada kurikulum sebelumnya, PPL memiliki bobot 8 SKS. Program tersebut diadakan selama semester tujuh dan perkuliahan di kampus 
PEDAGOGIA : Jurnal Ilmu Pendidikan

ditiadakan. Namun dalam KKNI, istilah tersebut diubah menjadi magang dan hanya memiliki bobot 4 SKS. Program tersebut dibagi menjadi tiga semester dengan menentukan mitra yang berbeda. Hal ini membuat pihak kampus kesulitan menemukan mitra sebagai wadah mahasiswa mengadakan magang.

Kendala keempat berkaitan dengan subjek KKNI itu sendiri, yakni mahasiswa. Mahasiswa sebagai pusat perhatian penerapan kurikulum berbasis kompetensi ini memiliki beberapa kesulitan yang juga mempengaruhi hasil yang diharapkan. Selain mahasiswa terkendala dengan masalah waktu pengerjaan tugas, mahassiswa juga cenderung kurang kreatif, kurang inovatif, dan kurang solutif dalam mengikuti pembelajaran KKNI. Selanjutnya, mahasiswa juga kurang mampu menggunakan bahasa Inggris, padahal ini sangat berpengaruh, mengingat banyaknya jurnal yang menggunakan bahasa Inggris. Dan hal yang paling mengejutkan, mahasiswa juga dianggap tidak memiliki kemauan untuk mengikuti perubahan pola belajar. Banyaknya tugas yang diberikan dosen membuat mahasiswa semakin malas mengerjakan. Tentu kendala ini belum lengkap, masih banyak yang mungkin belum teridentifikasi. Tetapi sebagai penelitian deskriptif kualitatif, kendala yang dipaparkan diperoleh dari lapangan secara alami dan murni.

\section{E. KESIMPULAN}

Berdasarkan penjelaasan di atas disimpulkan bahwa penerapan kurikulum berbasis KKNI di Universitas Negeri Medan sudah dikatakan baik, meskipun masih perlu perbaikan pada beberapa aspek seperti kesiapan dosen, kelengkapan sarana dan prasarana, ketersediaan mitra magang, dan tentunya kesiapan mahasiswa. Universitas harus terus membenahi diri agar para lulusan mampu bersaing dengan lulusan lain, baik secara local, nasional, maupun internasional.

\section{DAFTAR PUSTAKA}

Casmini. (2014). Evaluasi dan peninjauan kurikulum BKI berbasis KKNI. Hisbah, 11 (1), 125-144.

Depdiknas. (2010). Buku Pedoman Kerangka Kualifikasi Nasional Indonesia. Jakarta: Direktorat Jendral Pendidikan Tinggi.

Hutabarat, Diani. (2017, Oktober 4). Terapkan KKNI tingkatkan daya saing tenaga kerja Indonesia. Retrieved from https://kominfo.go.id/content/detail /10825/terapkan-kkni-tingkatkandaya-saing-tenaga-kerjaindonesia/0/berita satker.

Jono, A. A. (2016). Studi Implementasi Kurikulum Berbasis KKNI Pada Program Studi Pendidikan Bahasa Inggris Di LPTK Se-Kota Bengkulu. MANHAJ: Jurnal Penelitian dan Pengabdian Masyarakat, 4(1). 
Nurdin, H. S. (2018). Pengembangan kurikulum dan rencana pembelajaran semester (RPS) berbasis KKNI di perguruan tinggi. Jurnal Al-Ashlah, 2(1).

Peraturan Presiden Nomor 8 Tahun 2012. Kerangka Kualifikasi Nasional Indonesia. Jakarta: Sekretariat Negara.

Sinambela, P. (2017). Kurikulum Tingkat Satuan Pendidikan (Kajian Teoritis Tentang Evaluasi Kurikulum dalam Pembelajaran). GENERASI KAMPUS, 3(1).

Solikhah, I. (2015). KKNI dalam Kurikulum Berbasis Learning Outcomes. LINGUA: Journal of Language, Literature and Teaching, 12(1), 1-22.

Setiyawan, A. (2017). Model Penerapan Kualifikasi Kurikulum Nasional Indonesia (Kkni) Sebagai Penguatan Mutu Program Studi Pendidikan Bahasa Arab. Al Mahāra: Jurnal Pendidikan Bahasa Arab, 3(2)

Setiyawan, A. (2017). MODEL PENERAPAN KUALIFIKASI KURIKULUM NASIONAL INDONESIA (KKNI) SEBAGAI PENGUATAN MUTU PROGRAM STUDI PENDIDIKAN BAHASA ARAB. Al Mahāra: Jurnal Pendidikan Bahasa Arab, 3(2). 